\title{
Secretion of Metalloendopeptidase 24.15 (EC 3.4.24.15)
}

\author{
EMER S. FERRO, ${ }^{1,2}$ JOHN W. TULLAI, ${ }^{1}$ MARC J. GLUCKSMAN, ${ }^{1}$ and JAMES L. ROBERTS ${ }^{1}$
}

\begin{abstract}
The metalloendopeptidase EP24.15 (EC3.4.24.15) is a neuropeptide-metabolizing enzyme present in neural and endocrine tissues, presumably functioning extracellularly. Because the majority of the EP24.15 activity is identified in the soluble fraction of cellular homogenates, suggesting that the enzyme is primarily an intracellular protein, we addressed the issue of how EP24.15 arrives in the extracellular environment. We utilized a model system of neuroendocrine secretion, the AtT20 cell. According to both enzymatic activity and immunologic assays, EP24.15 was synthesized in and released from AtT20 cells. Under basal conditions and after stimulation by corticotropin-releasing hormone or the calcium ionophore A23187, EP24.15 activity accumulated in the culture medium. This secretion was not attributable to cell damage, as judged by the absence of release of cytosolic enzyme markers and the ability to exclude trypan blue dye. Pulse-chase analysis and subcellular fractionation of AtT20 cell extracts suggested that the mechanism of EP24.15 secretion is not solely via classical secretory pathways. Additionally, drugs which disrupt the classical secretory pathway, such as Brefeldin A and nocodazole, blocked A23187-stimulated EP24.15 release yet had no effect on basal EP24.15 release, suggesting differences in the basal and stimulated pathways of secretion for EP24.15. In summary, EP24.15 appears to be secreted from AtT20 pituitary cells into the extracellular milieu, where the enzyme can participate in the physiologic metabolism of neuropeptides.
\end{abstract}

\section{INTRODUCTION}

$\mathbf{E}$ NDO-OLIGOPEPTIDASES represent a distinct subclass of neuropeptide-metabolizing enzymes, exhibiting a restricted size selectivity for neuropeptides containing 8 to 17 amino acids (Oliveira et al., 1976; Camargo et al., 1997). These enzymes are easily distinguishable from other metallopeptidase s, such as neutral endopeptidase 24.11 or angiotensin I-converting enzyme, on the basis of their substrate and inhibitor specificity. The metalloendopep tidase 24.15 (EC 3.4.24.15; EP24.15) was initially described as endo-oligopeptida se A (Endo-A; formerly EC 3.4.22.19), a cytosolic thiol-dependent endopeptidase present in rabbit brain and responsible for the hydrolysis of the $\mathrm{Phe}_{5}-\mathrm{Ser}_{6}$ bond of bradykinin (Camargo et al., 1973; Carvalho and Camargo, 1981). Subsequently, a cytosolic, thiol-activated metalloendopep tidase similar to Endo-A was isolated from rat brain (Orlowski et al., 1983). Both enzymes were later classified as EC 3.4.24.15 (reviewed in Barrett et al., 1995). The EP24.15 enzyme is a soluble, 77-kDa endopeptidase, with an isoelectric point of 5.6 and a pH optimum of 7 (Orlowski et al.,
1983). The enzyme is broadly distributed, with high levels in neural and endocrine tissues such as brain, pituitary, ovary, and testis (Chu and Orlowski, 1985). In the brain, the enzyme is widely expressed but is enriched in areas such as the hippocampus and neuroendocrine hypothalamus (Oliveira et al., 1990; Healy and Orlowski, 1992; Wu et al., 1997).

Several neuropeptides are degraded/processed by EP24.15, such as bradykinin, neurotensin, and gonadotropin-relea sing hormone. Processing of the enkephalin-conta ining peptides, $\alpha$ and $\beta$-neoendorphin, dynorphin 1-8, Met-enkephalin- Arg-GlyLeu, and metorphamide to Met-/Leu-enkephalin has also been documented (Acker et al., 1987). Recently, EP24.15 has been implicated in the cleavage of nociceptin/orphanin FQ, an opioid receptor-like ligand (Montiel et al., 1997). Thus, this mainly cytosolic enzyme must access the outside of the cell to elicit its well-characteriz ed neuropeptide degrading/processing capabilities. Cell fractionation studies show the EP24.15 enzyme is present in a minor form in the particulate subcellular fractions (Acker et al., 1987; Oliveira et al., 1990), but the reported amino acid sequences derived from cDNA clones isolated from sev-

\footnotetext{
${ }^{1}$ Fishberg Research Center for Neurobiology, Mount Sinai Medical Center, New York, New York 10029.

${ }^{2}$ Department of Histology \& Embryology, São Paulo State University, São Paulo, Brazil.
} 
eral species do not contain a classical secretory signal for a secreted protein. Previous studies indicate calcium-independ ent secretion of EP24.15 from C6 glioma cells (Ferro et al., 1993).

In the present work, we utilized a well-described cell line model to better characterize the extracellular appearance of EP24.15, a basic requirement allowing this endopeptidase to participate in physiologic neuropeptide metabolism. The anterior pituitary AtT20 cell line was particularly useful for our studies because it contains EP24.15 enzymatic activity and immunoreactivity (Molineaux et al., 1988), and both the constitutive and regulated secretory pathways have been well characterized (Burgess and Kelly, 1987). Our present results suggest that EP24.15 is released from AtT20 cells in a manner which includes both the classical secretory pathways and an as yet undescribed secretory route.

\section{MATERIALS AND METHODS}

\section{Fluorimetric EP24.15 enzyme activity assay}

The EP24.15 enzymatic activity was determined fluorimetrically using the substrate Abz-GGFLRRV-EDDnp (QF7; Juliano et al., 1990). The QF7 substrate, a quenched fluorescent analog of dynorphin A (1-8), is cleaved at the L-R bond. To discern peptidolytic activity exclusively attributable to EP24.15, the inhibitors N-(1-(R,S)-carboxyl-2-phenyle thyl)AAF-p-amino-benzoate (CFP-AAF-pAB) or Pro-lle or both were used. All enzymatic determinations were conducted under linear conditions, where product formation is directly proportional to enzyme concentration and obeys first-order kinetic parameters with $<10 \%$ of the total substrate consumed during the course of the assay. The Abz-GGFL fluorescent product was used as a calibration standard. The enzyme assays were conducted in a final volume of $100 \mu 1$ containing 10 to $50 \mu 1$ of EP24.15 derived from cell extract/medium, $13 \mu \mathrm{M}$ of QF7, $1 \mathrm{mM} \beta$-mercaptoethano 1 , and TBS (0.025 M Tris HCl, $\mathrm{pH} 7.4$; $0.125 \mathrm{M} \mathrm{NaCl}$ ) adjusted to a total volume of $100 \mu 1$. After 30 min, the reactions were terminated with $1.9 \mathrm{ml}$ of $80 \mathrm{mM}$ sodium formate, $\mathrm{pH}$ 4.0. A milliunit of EP24.15 activity is defined as the amount of the enzyme (inhibited by CFP-AAFpAB but not by Pro-lle) able to hydrolyze 1 nmol of QF7/min/per milliliter at $37^{\circ} \mathrm{C}, \mathrm{pH} 7.5$, in TBS containing 1 $\mathrm{mM} \beta$-mercaptoethanol.

\section{Cell culture conditions and media/cell extraction of EP24.15}

The AtT20 anterior pituitary cell lines were cultured in Dulbecco Modified Eagle Medium (DMEM; Life Technologies, Grand Island, NY) containing 5\% fetal bovine serum (FBS), penicillin G $50 \mathrm{U} / \mathrm{ml}$, and streptomycin sulfate $50 \mu \mathrm{g} / \mathrm{ml}$ (complete medium; Life Technologies, Grand Island, NY) and incubated at $37^{\circ} \mathrm{C}$ in a humidified atmosphere consisting of $5 \%$ $\mathrm{CO}_{2}$ and $95 \%$ air. Basal and stimulated secretion of EP24.15 was determined by incubating the cells in DMEM containing $0.1 \%$ dialyzed bovine serum albumin (BSA) in the presence (stimulated) or absence (basal) of either calcium ionophore A23187 $(15 \mu \mathrm{M})$ or corticotropin-relea sing hormone (CRH; 10 $\mathrm{nM}$ ). Prior to each experiment, cells were rinsed three times with fresh DMEM containing $0.1 \%$ BSA for $1 \mathrm{~h}$. An appropri- ate volume of DMEM/0.1\% BSA medium was incubated for the same period of time in order to equilibrate the $\mathrm{CO}_{2}$ concentration and $\mathrm{pH}$. After the 1-h period, preequilibrated DMEM/ $0.1 \%$ BSA $0.5 \mathrm{ml} / \mathrm{cm}^{2}$ was used to replace the medium. At intervals of 15,30 , and 60 min or after a 60 -min incubation with the cells, the medium was removed, centrifuged for $30 \mathrm{sec}$ at $14,000 \times g$ to remove any cells or debris, and stored at $-20^{\circ} \mathrm{C}$ until analyzed. Storage at $-20^{\circ} \mathrm{C}$ for 2 weeks did not alter the enzyme activity of either EP24.15, cytosolic enzyme markers, or $\beta$-endorphin (data not shown).

Nocodazole $(30 \mu \mathrm{M})$ or Brefeldin A $(30 \mu \mathrm{M})$ were incubated with the cells in DMEM/0.1\% BSA medium for $2 \mathrm{~h}$. After the 2-h period, the medium was removed, and either nocodazole or Brefeldin A was again added to the cells in the presence or absence of A23187 $(15 \mu \mathrm{M})$ with fresh $\mathrm{DMEM} / 0.1 \% \mathrm{BSA}$. The medium was collected $1 \mathrm{~h}$ later, centrifuged to remove any cell debris, and stored at $-20^{\circ} \mathrm{C}$ until the assays were made.

\section{Subcellular fractionation and equilibrium density gradient centrifugation}

After removal of the culture medium, cells were rinsed at room temperature three times with phosphate buffered saline $(\mathrm{PBS})+\mathrm{Mg}^{+2}$, scraped in the same buffer with a rubber policeman, transferred to a plastic tube, and centrifuged at $800 \times$ $g$ for $5 \mathrm{~min}$ at room temperature. Cells were then resuspended in 1 to $2 \mathrm{ml}$ of ice-cold PBS/Mg $\mathrm{Mg}^{+2}$ and homogenized in an ice bath using a Potter-Elvehjem homogenizer equipped with a Teflon pestle. Nuclear, membrane, and cytosolic fractions were prepared as previously described (Roberts and Herbert, 1977). Ficoll equilibrium density gradient centrifugation was performed as previously described (Cramer and Cutler, 1992). Briefly, the AtT20 cell homogenate was centrifuged for $5 \mathrm{~min}$ at $11,000 \mathrm{rpm}$ in a microfuge at $4^{\circ} \mathrm{C}$. The post-nuclear supernatant liquid was gently layered on the top of a $1 \%$ to $16 \%$ linear Ficoll gradient and then centrifuged at $4{ }^{\circ} \mathrm{C}$ for $45 \mathrm{~min}$ at $30,000 \mathrm{rpm}$ in a Beckman SW40Ti rotor, $\beta$-Endorphin radioimmunoassays were conducted as described by the manufacturer (Peninsula Laboratories, Inc) using the Bridgette antibody (kindly provided by Dr. R. Allen, Oregon Health Sciences University). This antiserum recognizes $\beta$-endorphin and its precursors, $\beta$-LPH and proopiomelanoc ortin (POMC), on an equimolar basis and thus marks both secretory granules and rough endoplasm ic reticulum/Golgi apparatus, where POMC is synthesized and processed, making this a marker for the entire secretory pathway. Fractions 2 to 5 , containing the majority of the $\beta$-endorphin, were layered onto a $16 \%$ to $40 \%$ linear Ficoll gradient and centrifuged at $4^{\circ} \mathrm{C}$ for $17 \mathrm{~h}$ at $25,000 \mathrm{rpm}$ in a Beckman SW40Ti rotor. Fractions of $1 \mathrm{ml}$ each, starting from the bottom of the gradient, were collected and assayed for $\beta$ endorphin and EP24.15 enzymatic activity and protein.

\section{Determination of lactate dehydrogenase and glucose-6-phosphate dehyrogenase}

The LDH enzymatic activity was determined in AtT20 medium and cell extracts as described above with modifications (Schwartz and Bodansky, 1966), and the proportion of LDH activity released into the medium during the experimentation relative to LDH activity in the cell homogenate is referred to as 
"percent of cell leakage." One milliunit of LDH is defined as the amount of enzyme necessary to change one optical density (OD) unit at $340 \mathrm{~nm} / \mathrm{min}$ per milliliter in PBS (0.1 M phosphate buffer, $\mathrm{pH} 7.5$ ) containing $1.1 \mathrm{mM}$ sodium pyruvate and $0.24 \mathrm{mM} \beta$-NADH. Assay data were collected on an SLT 340 ATTC plate reader (TECAN, Research Triangle Park, NC) with 96-well capacity equipped with a kinetic software package.

Glucose-6-phosphate dehydrogenase (G6PD) activity was quantitated utilizing glucose-6-phosph ate as a substrate (Lee, 1982).

\section{Trypan blue exclusion assay}

Cells were rinsed with PBS and treated with $0.2 \%$ trypan blue in PBS for $90 \mathrm{sec}$. Excess dye was removed, and the cells were washed twice more with PBS and counted. The positive control consisted of a plate of cells treated with $50 \%$ ethanol for $1 \mathrm{~min}$ to permeabilize the cell membrane and then stained with the dye as described above. In this control, $>99 \%$ of the cells took up trypan blue.

\section{Protein concentration determination}

The protein concentration in cell extracts and subcellular fractions was determined by the Bradford assay (Bradford, 1976) using BSA as the standard.

\section{Affinity-purified antirecombinant rat testis EP24.15 antiserum}

A rabbit antiserum directed against rat EP24.15 was produced from the recombinant EP24.15 prepared and affinity purified with modifications as previously described (Glucksm an and Roberts, 1995). The expressed GST-rat EP24.15 fusion protein affinity column was washed first with TBS and then with TBS containing $2 \mathrm{M} \mathrm{KCl}$, and bound antibody was eluted with freshly prepared $\mathrm{Nal}(5 \mathrm{M})$ containing sodium thiosulfate (1 mM). Affinity-purified antirecombinant rat testis EP24.15 antibody was dispensed and stored at $-20^{\circ} \mathrm{C}$. There was no apparent crossreactivity ( $<1000$ fold) of this affinity-purified antiserum with the recombinant expressed enzyme EP24.16, kindly supplied by L. Hersh (University of Kentucky) (data not shown).

\section{Western immunoblotting}

Media samples obtained from AtT20 cells were concentrated 20-fold by ultrafiltration (Centricon C-30, Amicon, Beverly, MA), subjected to $8 \%$ SDS-PAGE (Laemmli, 1970), and electroblotted to a nitrocellulose membrane (Towbin et al., 1979) for $18 \mathrm{~h}$ at $35 \mathrm{~mA}$ using a Bio-Rad Trans-Blot cell. The amount of the concentrated medium used for Western immunoblotting represents $25 \%$ of the medium from a $10-\mathrm{cm}$ plate. The nitrocellulose membranes were subsequently incubated in $150 \mathrm{mM}$ $\mathrm{NaCl}, 1 \mathrm{mM}$ EDTA, $30 \mathrm{mM}$ Tris $\mathrm{HCl}$ buffer, $\mathrm{pH}$ 7.3; $0.05 \%$ Tween 20 , and $4 \% \mathrm{BSA}$ for $2 \mathrm{~h}$ at room temperature prior to incubation for $2 \mathrm{~h}$ at $4{ }^{\circ} \mathrm{C}$ with the primary affinity-purified antiserum 1:2000 and subsequently probed with ${ }^{125}$-I-anti-rabbit IgG secondary antibody (NEN-Dupont, Bedford, MA). Washing steps were performed at room temperature using TBS containing $0.15 \%$ Tween 20 ; the samples were blotted dry and exposed to X-ray film at $-80 \mathrm{C}^{\circ}$. Control experiments were conducted using either rabbit preimmune antiserum or excluding the primary antiserum in the first step; in both cases, no EP24.15 protein bands were observed.

\section{Pulse-chase and immunoprecipitation experiments}

AtT20 cells were grown in 12-well plates with DMEM containing 5\% FBS. Cells were rinsed three times and pulse-labeled with fresh pregassed (Cys and Met)-free DMEM/1\% dialyzed FBS containing $150 \mu \mathrm{Ci}$ of ${ }^{35} \mathrm{~S}$-methionine/cysteine labeling mix (NEN-Dupont, Bedford, MA) for $60 \mathrm{~min}$. After $60 \mathrm{~min}$, the labeling medium was removed, and the cells were rinsed and incubated with $1 \mathrm{ml}$ of regular DMEM complete medium for a 0 to 48 -h chase period and then harvested in 0.5 $\mathrm{ml}$ of NET buffer $(150 \mathrm{mM} \mathrm{NaCl}, 10 \mathrm{mM}$ Tris $\mathrm{Cl}, \mathrm{pH} 7.6 ; 1$ $\mathrm{mM}$ EDTA) containing protease inhibitors. The cells were homogenized by 20 strokes using a Potter-Elvehje $m$ homogenizer. The homogenate was centrifuged at $14,000 \times g$ for $20 \mathrm{~min}$, and the supernatant liquid (soluble fraction) was removed and complemented with detergent to form $1 \times$ RIPA buffer $(150 \mathrm{mM}$ $\mathrm{NaCl}, 0.1 \%$ SDS, $1 \%$ deoxycholate, $1 \%$ Triton $\mathrm{X}-100,10 \mathrm{mM}$ Tris $\mathrm{Cl}, \mathrm{pH} 7.6 ; 1 \mathrm{mM}$ EDTA). The remaining pellet (particulate fraction) was then solubilized in $1 \times$ RIPA.

The following procedures were used in both the pulse-chase experiments and immunoprecipitation of secreted EP24.15. For the immunoprecipitation procedures, particulate, soluble, and medium fractions were first clarified by centrifugation at $14,000 \times g$ for $5 \mathrm{~min}$, and the supernatant liquid was incubated for $60 \mathrm{~min}$ in the presence of $20 \mu \mathrm{l}$ of protein A-agarose (Sigma) to remove nonspecifically bound material. After centrifugation for $2 \mathrm{~min}$ at $10,000 \times g, 0.45 \mathrm{ml}$ of the supernatant liquid was removed and incubated for $2 \mathrm{~h}$ at $4^{\circ} \mathrm{C}$ in the absence (controls) or presence of $1 \mu \mathrm{g}(5 \mu \mathrm{l})$ of the affinity-purified anti-EP24.15 antibody. Again, any nonspecific aggregates were removed by centrifugation at $14,000 \times \mathrm{g}$, and the supernatant liquid was incubated for $20 \mathrm{~min}$ in the presence of $20 \mu \mathrm{l}$ of protein A-agarose and then recentrifuged. For characterization of the specific EP24.15 activity cleaving the QF7 substrate, the supernatant liquid was removed and used to quantify EP24.15 activity as described above.

For the pulse-chase experiments, the pellet was washed two times with $1 \mathrm{ml}$ of cold $1 \times$ RIPA buffer and once with a highsalt NET buffer (250 mM NaCl, $25 \mathrm{mM}$ Tris Cl, pH 7.6; $5 \mathrm{mM}$ EDTA). The protein A/antibody/EP24.15 complex was then disrupted by heating at $95^{\circ} \mathrm{C}$ in $50 \mu 1$ of SDS-PAGE sample buffer. Protein separations were conducted in an $8 \%$ polyacrylamide SDS-PAGE electrophoresis. Control experiments performed with recombinant EP24.15 protein indicated that as much as $50 \mathrm{ng}$ of pure protein could be quantitatively precipitated under the above conditions (data not shown). Gels were dried and then exposed to film at room temperature. Quantitation of the radioactivity per protein band was conducted utilizing a PhosphorImager analyzer (Molecular Dynamics, Sunnyvale, CA).

\section{Statistical analysis}

Secretion studies were routinely performed in triplicate from separate dishes of cells. Student's $t$-test was used to compare samples with the control culture, and significance was set at $p<0.05$. 


\section{RESULTS}

Secretion of EP24.15 from AtT20 cells occurred during culture in regular medium (basal secretion) and was stimulated with either a physiologic dose of CRH $(10 \mathrm{nM})$ or the calcium ionophore A23187 (15 $\mu \mathrm{M})$ (Fig. 1A). Release of EP24.15 protein into the medium by AtT20 cells was time dependent, as suggested by the Western blot experiments (Fig. 1B) and the pulse-chase experiments (Fig. 2) in parallel with the appearance of EP24.15 enzymatic activity (data not shown).

Addition of the EP24.15 inhibitor CFP-AAF-pAB $(3 \mu \mathrm{M})$ completely abolished QF7 substrate hydrolysis by the medium recovered after $1 \mathrm{~h}$ of incubation with AtT20 cells or in cells stimulated with CRH or A23187 (data not shown). Secretion

A
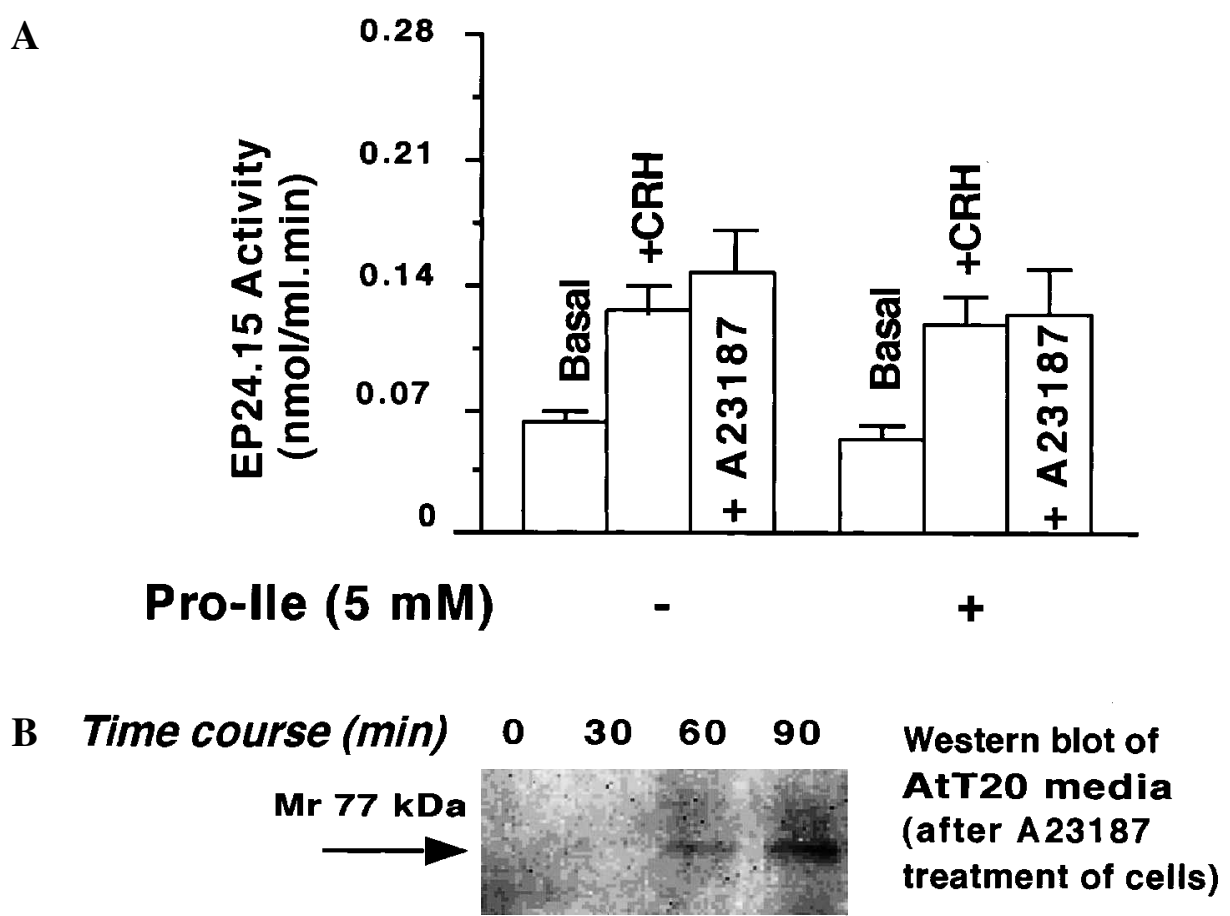

C

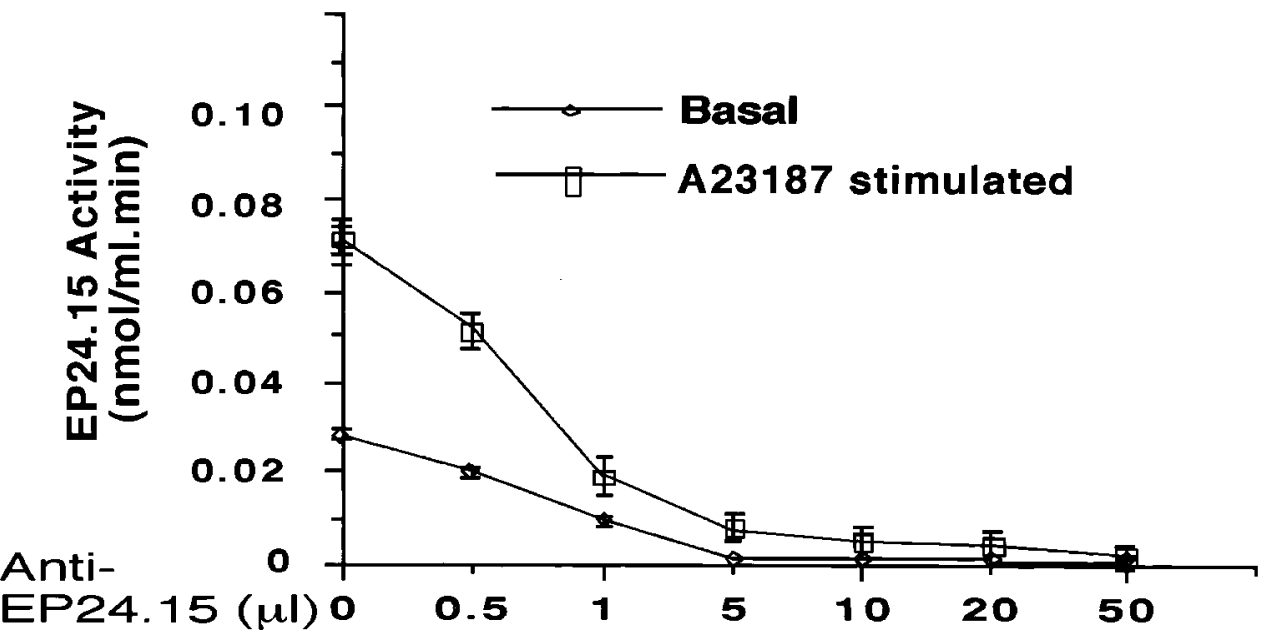

FIG. 1. Characterization of EP24.15 secretion from AtT20 cells. (A) EP24.15 enzyme activity was measured in medium collected after incubating the cells for $1 \mathrm{~h}$ in the absence (basal) or presence (stimulated) of CRH (10 nM) and A23187 (15 $\mu \mathrm{M})$. The EP24.15 activity was assayed with the QF7 substrate as described in Materials and Methods. The effect of the dipeptide Pro-lle (a selective inhibitor of EP24.16) on the hydrolysis of QF7 by medium from AtT20 cells was quantitated. Results are expressed as medium activity \pm SD of four individual determinations in duplicate. (B) Western immunoblot analysis of medium (see Materials and Methods) from A23187-stimulated AtT20 cells conducted with the affinity-purified EP24.15. (C) Immunopreciptation to remove the EP24.15 enzyme was performed with affinity-purified EP24.15 antiserum. Results are medium \pm SD of four individual determinations in duplicates. 

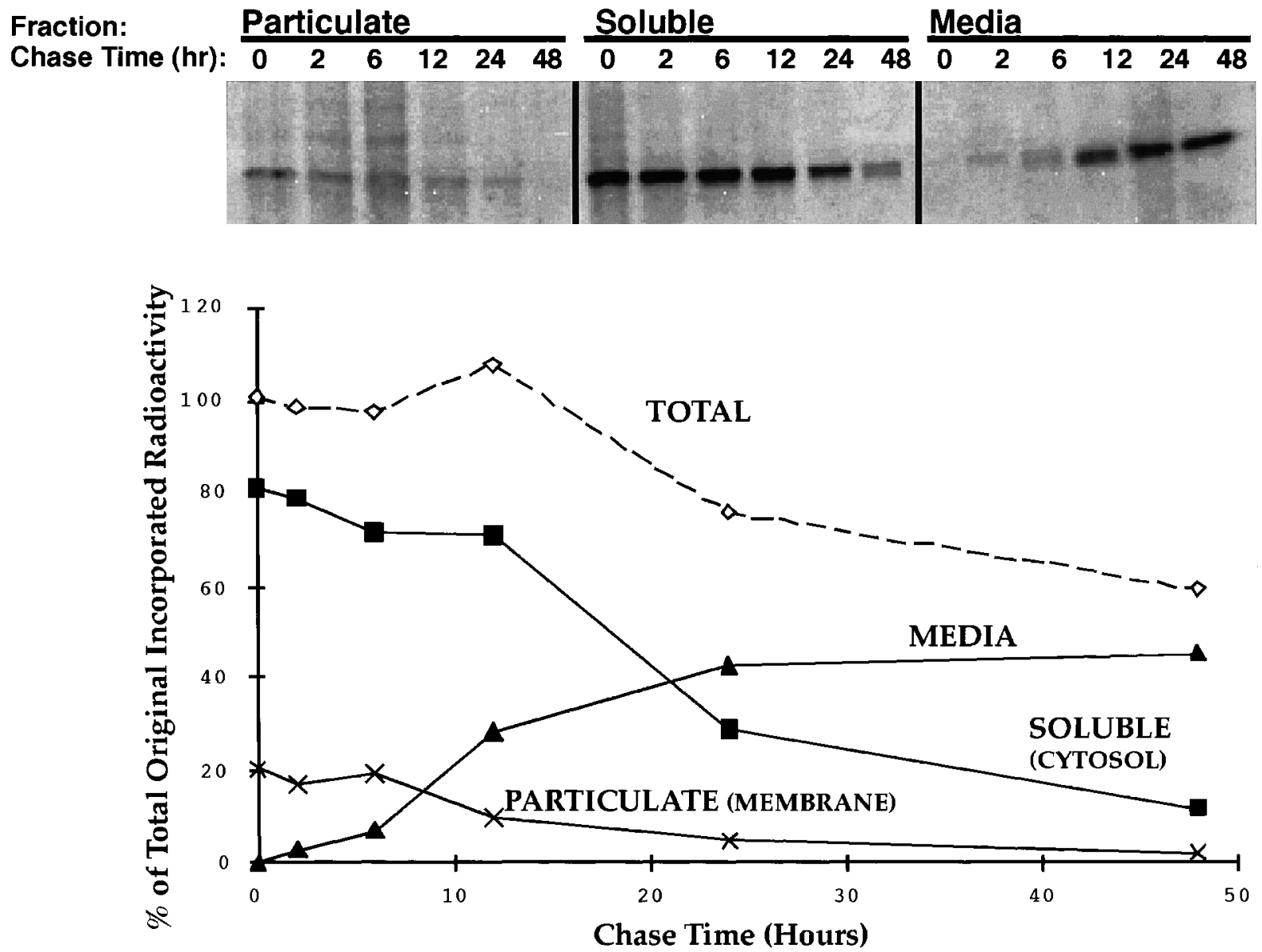

FIG. 2. Pulse-chase of metabolically labeled AtT20 cells followed by immunoprecipitation of EP24.15. AtT20 cells were pulsed with ${ }^{35} \mathrm{~S}(\mathrm{Met}+\mathrm{Cys})$ and chased for various times up to $48 \mathrm{~h}$, and EP24.15 was immunoprecipitated from subcellular fractions (described in Materials and Methods) for subsequent quantitation by PhosphorImager analysis. The data represent the mean of two independent experiments.

of the endopeptidase EC 3.4.24.16 (EP24.16) was not detected in our experiments using the QF7 substrate, as there was no significant change in the substrate hydrolysis on addition of 5 mM Pro-lle, an EP24.16 inhibitor (Dauch et al., 1991) (Fig. 1A). This observation is supported by immunoprecipitation of the medium with an affinity-purified EP24.15-specific antiserum, which removed all QFS hydrolyzing activity (Fig. 1C) under both basal and A23187-stimu lated conditions. Additional results obtained with the neutral endopeptidase 24.11 inhibitor phosphoramidon $(10 \mu \mathrm{M})$ and the angiotensin-conv erting enzyme inhibitor captopril $(10 \mu \mathrm{M})$ also indicated that these metalloenzym es are not contributing to the catabolism of the QF7 substrate.

The possibility of nonspecific release of EP24.15 from AtT20 cells secondary to cell damage was evaluated. The cellular and medium content of enzymatic activity for EP24.15 and $\mathrm{LDH}$, a cytosolic enzyme marker, were measured under basal conditions and after stimulation with CRH or A23187. Under basal conditions, $3.4 \%(0.071 \pm 0.008 \mathrm{mU})$ of cellular EP24.15 activity was secreted after $1 \mathrm{~h}$ of incubation from a total enzyme activity in the AtT20 cells of $2.1 \pm 0.4 \mathrm{mU}$. After a 60-min stimulation with A23187, the specific EP24.15 activ- ity secreted into the medium $(0.177 \pm 0.016 \mathrm{mU})$ represented $8.4 \%$ of the total cell extract activity $(2.1 \pm 0.4 \mathrm{mU})$. No LDH activity could be detected in the incubation medium of AtT20 cells in the first hour under basal or CRH-stimulated conditions. After A23187 ionophore stimulation of the cells, LDH activity in the medium increased to $2 \%(0.015 \pm 0.01 \mathrm{mU})$ of the total cell activity $(0.69 \pm 0.02 \mathrm{mU})$. Results consistent with these observations were also obtained measuring another cytosolic marker, G6PD (data not shown). Furtherm ore, trypan blue exclusion indicated that after a 60-min treatment with either CRH or A23187, $>99 \%$ of the cells remained viable. Neither CRH nor A23187 added to the assay medium by itself directly affected the enzymatic activity measurem ents for either EP24.15 or LDH (data not shown).

The time course of basal secretion of newly synthesized EP24.15 was then investigated using a pulse-chase paradigm. To analyze for possible constitutive secretion of EP24.15, AtT20 cells were pulse-labeled with ${ }^{35} \mathrm{~S}(\mathrm{Met}+\mathrm{Cys})$ for $1 \mathrm{~h}$ and chased for various times (0-48 h; Figure 2). The immunoprecipitated ${ }^{35} \mathrm{~S}\left(\right.$ Met + Cys)-labeled EP24.15 migrated at $\mathrm{M}_{\mathrm{r}} 77$ $\mathrm{kDa}$ (Fig. 2, top panel). The majority of pulse-labeled EP24.15 was maintained within the AtT20 cells during the first hours 
after the ${ }^{35} \mathrm{~S}$ (Met + Cys) pulse, and only after 6 to $12 \mathrm{~h}$ of chase did detectable ${ }^{35} \mathrm{~S}$ (Met+Cys)-labeled EP24.15 appear in the medium (Fig. 2). The increase of EP24.15 in the medium occurred concomitantly with and proportionally to a decrease in both soluble and particulate (crude membrane) ${ }^{35} \mathrm{~S}$ (Met + Cys)labeled EP24.15 fractions (Fig. 2).

Ficoll gradient equilibrium density centrifugation experiments suggested the presence of EP24.15 enzyme activity and immunoreactivity in the secretory pathway. An initial $1 \%$ to $16 \%$ Ficoll gradient was ultracentrifuged, and the fractions that contained the bulk of $\beta$-endorphin, a marker for secretory pathway vesicles, were collected. As expected for a predominantly cytosolic protein, EP24.15 was enriched in the top gradient fractions; however, $15 \%$ of the activity was distributed in the denser fractions ( $3-5$ from the bottom), where the $\beta$-endorphin content was concentrated (data not shown). In the subsequent $16 \%$ to $40 \%$ Ficoll gradient, fractions 3 to 5 from the first Ficoll gradient were further analyzed; $\beta$-endorphin immunoreactiv ity was detected in fractions 4 to 10 (Fig. 3). The EP24.15 activity overlap with $\beta$-endorphin occurred in fractions 7 to 10 (Fig. 3). A similar distribution pattern was observed when EP24.15 protein content was developed by Western blots (Fig. 3, upper panel). Although equal amounts of each fraction were analyzed, the Western immunoblot signal in this figure is a qualitative, not quantitative, reflection of EP24.15 protein. Thus, there is overlap between EP24.15 and a portion of the $\beta$-endorphin, a marker for the classical secretory pathway components in AtT20 cells.

The effect of inhibitors of intracellular vesicular trafficking (disrupting the classical secretory pathways) on the specific
EP24.15 activity secreted by AtT20 cells is shown in Figure 4. Brefeldin A, which blocks protein transport from the ER to the Golgi apparatus, and nocodazole, which inhibits vesicular transport by dissociating microtubules, were utilized. Neither nocodazole nor Brefeldin A altered basal EP24.15 secretion from AtT20 cells after $1 \mathrm{~h}$ of treatment (Fig. 4A). However, both brefeldin A and nocodazole efficiently blocked A23187-stimulated EP24.15 secretion from AtT20 cells (Fig. 4A). Secretion of a peptide marker from secretory vesicles, $\beta$-endorphin, was similarly analyzed with basal or CRH-stimulated release, in the presence of either nocodazole or brefeldin A, which both blocked CRH-stimulated release (Fig. 4B).

\section{DISCUSSION}

The biologic action of neuropeptides is terminated extracellularly by proteolytic enzymes, which must have the catalytic site situated at or beyond the outer surface of the plasma membrane (Medeiros and Turner, 1994). Whereas some neuropeptidases, such as neutral endopeptidase or angiotensin-converting enzyme, are bound to the membrane via a hydrophobic transmembrane segment and contain ectodomains with catalytic activity, EP24.15 does not contain this membrane anchoring motif. Earlier studies using C6 glioma cells suggested that EP24.15 can be released into the medium (Ferro et al., 1993), but these cells do not represent a refined model of regulated secretion. Therefore, in the present study, we investigated the release of EP24.15 into the extracellular medium in a well-established cell culture system for examining secretion: AtT20 cells.

\section{EP 24.15 Western blot fractions}

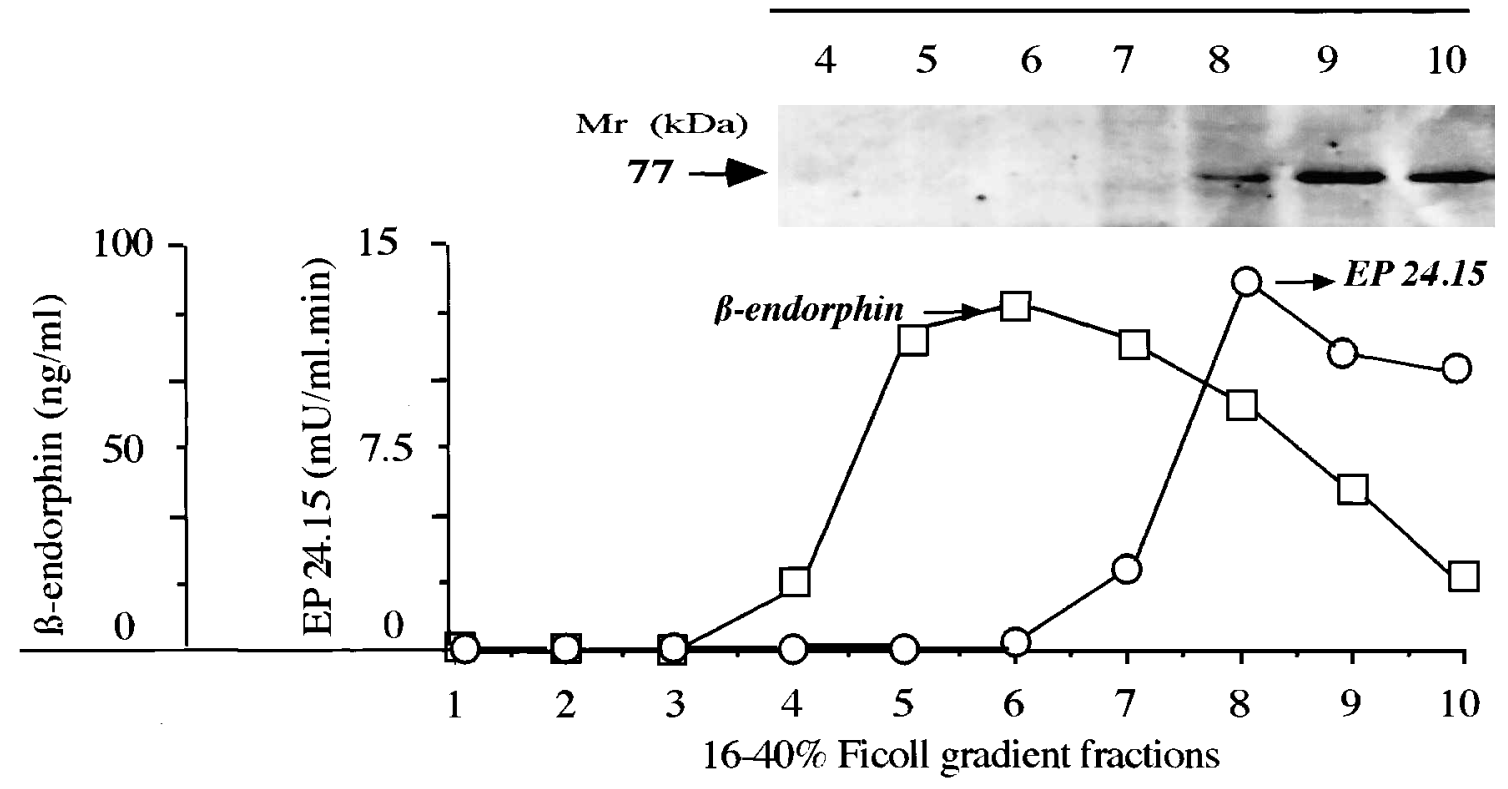

Bottom - - - - - $--------\rightarrow$ Top

FIG. 3. EP24.15 enzyme activity and immunoreacti vity after fractionation of AtT20 cells. Cells were homogenized as described in Materials and Methods. Fractions $(1 \mathrm{ml})$ from the second 16\% to $40 \%$ Ficoll gradient, starting from the bottom of the gradient, were collect using a needle and assayed for $\beta$-endorphin and EP24.15 enzyme activity and immunoreactivity (upper panel), as detailed in Materials and Methods. 


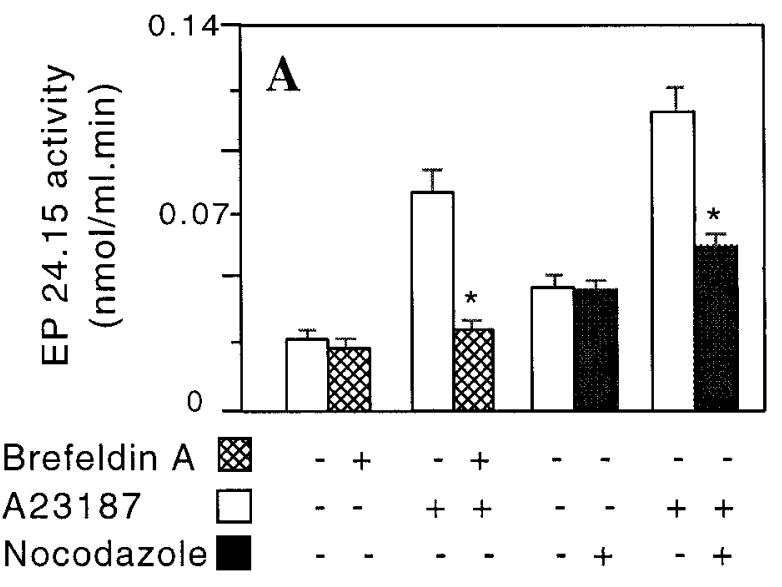

Secretion of EP24.15 under basal conditions was shown to be attributable mainly to specific release and not to cell leakage, as activity of the cytoplasmic enzymes LDH and G6PD was not found in the medium during the time course of our experiments. The ability of these cells to completely exclude trypan blue before CRH or A23187 treatment also suggested that basal release of EP24.15 into the medium was not a consequence of cell death. After CRH or A23187 treatment, there was an increase in LDH and G6PD activity in the medium that might explain some of the EP24.15 appearance if it was secondary to cell leakage. However, only $2 \%$ of the intracellular LDH or G6PD activity appeared in the medium compared with $8.4 \%$ of the total EP24.15, suggesting that only about $20 \%$ of EP24.15 secreted into the medium under CRH or A23187 treatments could be attributed to a nonspecific mechanism such as cell lysis. Taken together, these results suggest that EP24.15 is secreted by AtT20 cells in the basal state and release is enhanced by factors known to stimulate $\beta$-endorphin release.

The protein motif(s) responsible for aiding EP24.15 translo-
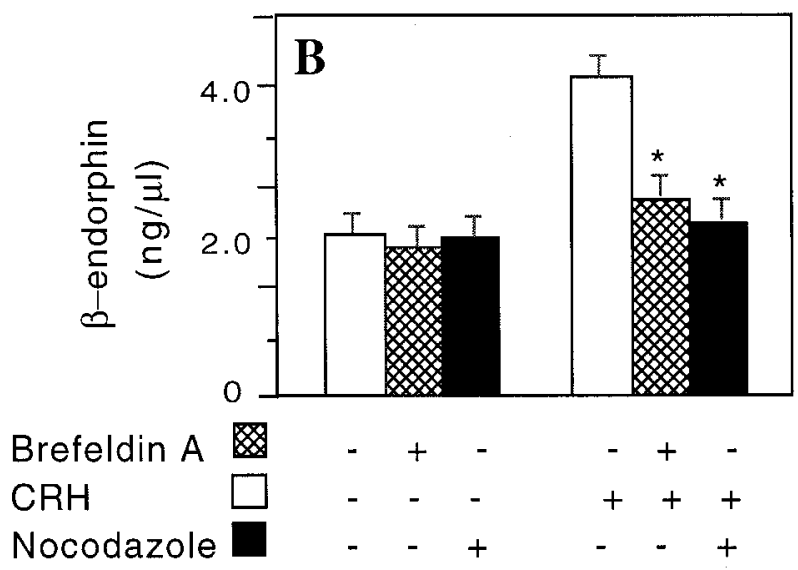

FIG. 4. Pharmacologic modulation of EP24.15 and $\beta$-endorphin basal and stimulated secretion. The AtT20 cells were grown to $70 \%$ to $80 \%$ confluence and preincubated for $2 \mathrm{~h}$ in DMEM containing $0.1 \%$ dialyzed BSA with $30 \mu \mathrm{M}$ of either brefeldin A or nocodazole. The medium was replaced with fresh medium containing the same concentration of nocodazole or Brefeldin A, with or without $15 \mu \mathrm{M} \mathrm{A} 23187$, assaying for EP24.15 activity (A) or adding $10 \mathrm{nM} \mathrm{CRH}$ and measuring $\beta$ endorphin secretion (B). After a 1-h incubation, the medium was removed, briefly centrifuged, and kept at $-20^{\circ} \mathrm{C}$ until the enzyme assay or RIA was performed. Data are the average \pm $\mathrm{SD}$ of four independent determinations. Significance was calculated using a two-tailed $t$-test. $p<0.001$ compared with A23187 or CRH alone.

Several lines of evidence indicate that EP24.15 is secreted from AtT20 cells, and that this secretion can be regulated. The QF7 degrading activity released under basal conditions or after CRH treatment of AtT20 cells appeared to be attributable solely to EP24.15, as judged by the complete inhibition by either CFP-AAF-pAB inhibitor addition or by immunoprecipitation using the affinity-purified anti-EP24.15 antiserum. Confirming EP24.15 release into the medium, Western immunoblotting of concentrated medium exhibited an EP24.15immunoreactive $77-\mathrm{kDa}$ band which increased in intensity as the enzyme activity increased over time. acid sequence of rat testis EP24.15, as deduced from its cDNA, contains neither a signal peptide sequence nor a putative transmembrane hydrophobic domain for protein translocation between subcellular compartments (Pierotti et al., 1990). Similar conclusions come from sequence analysis of putative EP24.15 from other species (Barrett et al., 1995). Whereas most proteins destined for secretion are made on membrane-bound ribosomes and enter either the regulated or the constitutive vesicular pathway, there are anomalies. A nonclassical secretory pathway has been suggested for proteins destined for secretion that lack known signals to enable them to traverse membranes. This route, obviating a path through the ER for secretory proteins lacking hydrophobic signals, allows synthesis of these proteins in the cytosol, followed by their exit from the cell in mature form (Kuchler and Thorner, 1990). Other secretory proteins that lack signal sequences yet traverse the plasma membrane are the lectin L29 (Lindstedt et al., 1993), yeast pheromone a-mating factor (McGrath and Varshavsky, 1989), acidic and basic fibroblast growth factors (a- and b-FGF) (Mignatti et al., 1992; Cao and Petterson, 1993; Florkiewicz et al., 1998), interleukin $1 \alpha$ and $1 \beta$ (Hazuda et al., 1988; Rubartelli et al., 1990; Hamon et al., 1997), and EP24.16 (Vincent et al., 1996). Export of the yeast a-factor and interleukin $1 \beta$ appear to rely on ATP-dependent membrane proteins related to the $\mathrm{ABC}$ transporter, STE6 (Endicott and Ling, 1989; Michaelis, 1993; Hamon et al., 1997). Secretion of the related enzyme, cytosolic EP24.16, was demonstrated in astrocyte cultures (Vincent et al., 1996), but the secretory mechanism has yet to be described.

Our studies on EP24.15 suggest that its appearance in the medium of AtT20 cells under either stimulated or basal conditions could be only partially explained by transit through the classical secretory mechanism. Temporally, proteins entering the constitutive secretory pathway are synthesized and secreted within the first few hours, whereas protein secreted via the regulated secretory pathway can remain intracellular for hours to days after synthesis (Steiner, 1991). In AtT20 cells, pulse-chase labeling studies on the POMC peptide system, which utilizes both pathways, showed that stably labeled POMC precursor (a marker of the constitutive pathway) was chased completely out of the cell within $4 \mathrm{~h}$ (Eipper and Mains, 1980; Roberts et al., 
1978), indicating that the constitutive pathway has been turned over after this time. Because our work indicates that at least 6 $\mathrm{h}$ of chase time is necessary for ${ }^{35} \mathrm{~S}$ (Met + Cys)-labeled EP24.15 to appear in the medium (see Fig. 2) and basal EP24.15 release is unaffected by the classical secretory pathway inhibitors, the constitutive secretory pathway probably is not a significant route through which basal EP24.15 secretion occurs.

Importantly, EP24.15 is not localized exclusively in the cytosolic compartment of AtT20 cells, as demonstrated by pulsechase experiments (Fig. 2). A portion (15\%-20\%) of the enzyme appears to be present in vesicular components, as both enzyme activity and immunoreactive protein colocalize with $\beta$ endorphin in Ficoll density gradient centrifugation (Fig. 3). The $\beta$-endorphin marker exhibits a broader distribution on the gradient, as the antibody also recognizes the unprocessed precursor protein in the ER/Golgi apparatus. Thus, we interpret the overlap of this portion of the marker as indicative of its presence in the secretory pathway as a whole. Therefore, stimulated secretion of EP24.15 could be attributable to the exocytosis of secretory granules containing the enzyme. How the enzyme enters secretory granules is unclear without a signal sequence to target these organelles. Possibly, the nonclassical mechanism discussed above for a- and b-FGF, interleukin $1 \beta$, etc. concentrates EP24.15 in the vesicular secretory machinery.

Pretreatment of AtT20 cells with brefeldin A, blocking trafficking from the ER to the Golgi apparatus, inhibited $\sim 75 \%$ of calcium ionophore (A23187)-stimulated EP24.15 secretion, with no effect on basal enzyme secretion. Nocodazole, known to disrupt microtubules, which in turn are necessary for vesicular movement from the trans-Golgi network to the plasma membrane, also inhibited A23187-stimulated EP24.15 secretion, without effect on basally secreted EP24.15 (see Fig. 4A). The inhibitory effects of either brefeldin A or nocodazole only on EP24.15-stimulated secretion suggests a role of EP24.15 transiting through the classical secretory pathway, similar to $\beta$-endorphin. Immunocytochemical evidence has recently shown EP24.15 to be present in the classical, regulated secretory pathway (Garrido et al., 1999). The findings presented in this paper support this finding with respect to the classically secreted EP24.15.

Other evidence supports the observation that at least a portion of the secreted EP24.15 is derived from the cytoplasm (see Fig. 2). After the labeling ${ }^{35}$ S-Met/Cys pulse, only $\sim 20 \%$ of the newly synthesized EP24.15 was associated with the particulate (vesicular) fraction, whereas $>40 \%$ of the pulse-labeled material appeared in the medium. Indeed, it appears that both the soluble and the particulate fractions are contributing to the labeled enzyme appearing in the medium.

Despite the lack of evidence for a membrane-targeting motif in the EP24.15 sequence (Pierotti et al., 1990), there is a possibility that other forms of EP24.15 exist to target the enzyme to the secretory pathway and then to the extracellular milieu (see Fig. 1). The related enzym e EP24.16 exhibits alternate transcriptional start sites and alternatively spliced transcripts, producing multiple mRNAs (Kato et al. 1997). These mRNAs encode distinct forms of the EP24.16 enzyme, shown to target either the mitochondria or the cytosol (Kato et al., 1997). The porcine EP24.16 gene encodes neither a signal peptide sequence nor any other hydrophobic sequence (Kato et al., 1997), similar to EP24.15, but EP24.16 secretion and membrane association have also been reported (Vincent et al., 1997). Therefore, it is possible that both rat EP24.15 and EP24.16, which share
$63 \%$ identity at the amino acid level, are using nonclassical routes to enter the secretory pathway and to associate with the plasma membrane. Alternatively, there exists for both EP24.15 and EP24.16 another form of the enzyme containing distinct structural determinant(s) for alternate targeting paths. Ongoing studies are exploring this possibility.

Taken together, the data indicate that EP24.15 can be secreted in a time-dependent and regulated fashion for relevant physiologic action in the extracellular environment. The mechanism of secretion appears to involve the classical, regulated secretory pathway, with a major contribution from a nonclassical secretory component. It is hoped that further investigation will aid in a better understanding of the molecular and cellular basis of EP24.15 translocation.

\section{ACKNOWLEDGMENTS}

We thank Dr. Ian Smith (Baker Medical Research Inst., Melbourne, Australia), who provided the CFP-AAF-pAb inhibitor, and Dr. Luiz Juliano (Paulista Medical School, São Paulo, Brazil) for providing the QF7 substrate. We are grateful for the technical expertise of Mr. Elliott Margulies and Dr. Joshua Berman (Mount Sinai Medical Center). We are grateful to Drs. Marcelo D. Gomes, Denise V. Tambourgi, and Antonio C.M. Camargo (Butantan Inst., São Paulo) and Mauro Sucupira (University of São Paulo) for aid in the initial phase of this work. This work was partially supported by grants from CNPq and FAPESP (to ESF), the American Foundation for Aging Research (to MJG), U.S. Public Health Service T32-DK07645 (to JWT), and the National Institutes of Health NS37421 (to JLR and MJG).

\section{REFERENCES}

ACKER, G.R., MOLINEAUX, C., and ORLOWSKI, M. (1987). Synaptosomal membrane-bound form of endopeptidase 24.15 generates Leu-enkephalin from dynorphin 1-8, $\alpha$ - and $\beta$-neoendorphin and Met-enkephalin from Met-enkephalin- $\mathrm{Arg}^{6}-\mathrm{Gly}^{7}-\mathrm{Leu}^{8}$. J. Neurochem. 48, 284-292.

BARRETT, A.J., BROWN, M.A., DANDO, P.M., KNIGHT, C.G., MCKIE, N., RAWLINGS, N.D., and SERIZAWA, A. (1995). Thimet oligopeptidase and oligopeptidase M or neurolysin. Methods Enzymol. 248, 529-556.

BRADFORD, M.M. (1976). A rapid and sensitive method for the quantitation of microgram quantities of protein utilizing the principle of protein-dye binding. Anal. Biochem. 72, 248-254.

BURGESS, T.L., and KELLY, R.B. (1987). Constitutive and regulated secretion of proteins. Annu. Rev. Cell Biol. 3, 243-293.

CAMARGO, A.C., GOMES, M.D., REICHL, A.P., FERRO, E.S., JACCHIERI, S., HIRATA, I.Y., and JULIANO, L. (1997). Structural features that make oligopeptides susceptible substrates for hydrolysis by recombinant thimet oligopeptidase. Biochem. J. 324, 517-522.

CAMARGO, A.C.M., SHAPANKA, R., and GREENE, L.J. (1973). Preparation, assay and partial characterization of a neutral endopeptidase from rabbit brain. Biochemistry 12, 1838-1844.

CAO, Y., and PETTERSON, R.F. (1993). Release and subcellular localization of acidic fibroblast growth factor expressed to high levels in HeLa cells. Growth Factors 8, 277-290.

CARVALHO, K.M., and CAMARGO, A.C. (1981). Purification of rabbit brain endooligopeptidase $\mathrm{s}$ and preparation of anti-enzyme antibodies. Biochemistry 20, 7082-7088.

CHU, T.G., and ORLOWSKI, M. (1985). Soluble metallopeptidase 
from rat brain: Action on enkephalin-contai ning peptides and other bioactive peptides. Endocrinology 116, 1418-1425.

CRAMER, L.P., and CUTLER, D.F. (1992). Sorting between exocytic pathways in PC12 cells. In Protein Targeting: A Practical Approach A.L. Magee and T. Wileman, eds. (Oxford University Press, Oxford) pp. 59-86.

DAUCH, P., VINCENT, J.P., and CHECLER F. (1991). Specific inhibition of endopeptidase 24.16 by dipeptides. Eur. J. Biochem. 202, 269-276.

EIPPER, B.A., and MAINS, R.E. (1980). Structure and biosynthesis of pro-adrenocorticotropin/endorphin and related peptides. Endocrinol. Rev. 1, 1-27.

ENDICOTT, J.A., and LING, V. (1989). The biochemistry of P-glycoprotein-mediated multidrug resistance. Annu. Rev. Biochem. 58, 131-171.

FERRO, E.S., TAMBOURGI, D.V., GOBERSZTEJN, F., GOMES, M.D., SUCUPIRA, M., ARMELIN, M.C.S., KIPNIS, T.L., and CAMARGO, A.C.M. (1993). Secretion of a neuropeptide-m etabolizing enzyme similar to endopeptidase 22.19 by glioma C6 cells. Biochem. Biophys. Res. Commun. 191, 275-281.

FLORKIEWICZ, R.Z., ANCHIN, J., and BAIRD, A. (1998). The inhibition of fibroblast growth factor- 2 export by cardenolides implies a novel function for the catalytic subunit of $\mathrm{Na}^{+}, \mathrm{K}^{+}$-ATPase. J. Biol. Chem. 273, 544-551.

GLUCKSMAN, M.J., and ROBERTS, J.L. (1995). Strategies for characterizing and cloning endopeptidases. Methods Neurosci. 23, 296-316.

GARRIDO, P.A.G., VANDENBULKE, F., RAMJAUN, A.R., VINCENT, B., CHECLER, F., FERRO, E., and BEAUDET, A. (1999). Confocal microscopy reveals thimet oligopeptidase (EC 3.4.24.15) and neurolysin (EC 3.4.24.16) in the classical secretory pathway. DNA Cell Biol. 18, 323-331.

HAMON, Y., LUCIANI, M.F., BECQ, F., VERRIER, B., RUBARTELLI, A., and CHIMINI, G. (1997). Interleukin-1be ta secretion is impaired by inhibitors of the ATP binding cassette transporter, ABC1. Blood 90, 2911-2915.

HAZUDA, D.J., LEE, J.C., and YOUNG, P.R. (1988). The kinetics of interleukin-1 secretion from activated monocytes. J. Biol. Chem. 263, 8473-8479.

HEALY, D.P., and ORLOWSKI, M. (1992). Immunocytochemical localization of endopeptidase 24.15 in rat brain. Brain Res. 571, 121-128.

JULIANO, L., CHAGAS, J.R., HIRATA, I.Y., CARMONA, E., SUCUPIRA, M., OLIVEIRA, E.S., OLIVEIRA, E.B., and CAMARGO, A.C. (1990). A selective assay for endooligopeptidase A based on the cleavage of fluorogenic substrate structurally related to enkephalin. Biochem. Biophys. Res. Commun. 173, 647-652.

KATO, A., SUGIURA, N., SARUTA, Y., HOSOIRI, T., YASUE, H., and HIROSE, S. (1997). Targeting of endopeptidase 24.16 to different subcellular compartments by alternative promoter usage. J. Biol. Chem. 272, 15313-15322.

KUCHLER, K., and THORNER, J. (1990). Membrane translocation of proteins without hydrophobic signal peptides. Curr. Opin. Cell Biol. 2, 617-624.

LAEMMLI, U.K. (1970). Cleavage of structural proteins during the assembly of the head of bacteriophage T4. Nature 227, 680-685.

LEE, C.Y. (1982). Glucose-6-phosphate dehydrogenase from mouse. Methods Enzymol. 89, 252-257.

LINDSTEDT, R., APODACA, G., BARONDES S.H., MOSTOV, K.E., and LEFFLER, H. (1993). Apical secretion of a cytosolic protein by Madin-Darby canine kidney cells: Evidence for polarized release of an endogenous lectin by a nonclassical secretory pathway. J. Biol. Chem. 268, 11750-11757.

MCGRATH, J.P., and VARSHAVSKY, A. (1989). The yeast STE6 gene encodes a homologue of the mammalian multidrug resistance P-glycoprotein. Nature 340, 400-404.

MEDEIROS, M.S., and TURNER, A.J. (1994). Post-secretory processing of regulatory peptides: The pancreatic polypeptide family as a model example. Biochimie 76, 283-287.
MICHAELIS, S. (1993). STE6, the yeast a-factor transporter. Semin. Cell Biol. 4, 17-27.

MIGNATTI, P., MORIMOTO, T., and RIFKIN, D.B. (1992). Basic fibroblast growth factor, a protein devoid of secretory signal sequence, is released by cells via a pathway independent of the endoplasmic reticulum-Golgi complex. J. Cell Physiol. 151, 81-93.

MOLINEAUX, C.J., LASDUN, A., MICHAUD, C., and ORLOWSKI, M. (1988). Endopeptidase 24.15 is the primary enzyme that degrades luteinizing hormone releasing hormone both in vitro and in vivo. $\mathrm{J}$. Neurochem. 51, 624-633.

MONTIEL, J.L., CORNILlE, F., ROQUES, B.P., and NOBLE, F. (1997). Nociceptin/orphanin FQ metabolism: Role of aminopeptidase and endopeptidase 24.15. J. Neurochem. 68, 354-361.

OLIVEIRA, S.E., LEITE, P.E.P., SPILLANTINI, M.G., CAMARGO, A.C.M., and HUNT, P.S. (1990). Localization of endo-oligopeptidase (EC 3.4.22.19) in the rat nervous tissue. J. Neurochem. 55, 1114-1121.

OLIVEIRA, E.B., MARTINS, A.R., and CAMARGO, A.C. (1976). Isolation of brain endopeptidases: Influence of size and sequence of substrates structurally related to bradykinin. Biochemistry $\mathbf{1 5}$, 1967-1974.

ORLOWSKI, M., MICHAUD, C., and CHU, T.G. (1983). A soluble metalloendopepti dase from rat brain. Eur. J. Biochem. 135, 81-88.

PIEROTTI, A., DONG, K.W., GLUCKSMAN, M.J., ORLOWSKI, M., and ROBERTS, J.L. (1990). Molecular cloning and primary structure of rat testes metalloendopeptid ase EC 3.4.24.15. Biochemistry 29, 10323-10329.

ROBERTS, J.L., and HERBERT, E. (1977). Characterization of a common precursor to corticotropin and beta-lipotropin: Cell-free synthesis of the precursor and identification of corticotropin peptides in the molecule. Proc Natl Acad Sci USA 74, 4826-4830.

ROBERTS, J.L., PHILliPS, M., ROSA, P.A., and HERBERT, E. (1978). Steps involved in the processing of common precursor forms of adrenocorticotropin and endorphin in cultures of mouse pituitary cells. Biochemistry 17, 3609-3618.

RUBARTElli, A., COZZOlino, F., TAlio, M., AND Sitia, R. (1990). A novel secretory pathway for interleukin-1 $\beta$, a protein lacking a signal sequence. EMBO J. 9, 1503-1510.

SCHWARTZ, M.K., and BODANSKY, O. (1966). Lactate dehydrogenase (clinical aspects). Methods Enzymol. 9, 294-302.

STEINER, D.F. (1991). The biosynthesis of biologically active peptides: A perspective. In Peptide Biosynthesis and Processing. L.D. Fricker, ed. (CRC Press, Boca Raton, FL) pp. 1-15.

TOWBIN, H., STAEHELIN, T., and GORDON, J. (1979). Electrophoretic transfer of proteins from polyacrylamide gels to nitrocellulose sheets: Procedure and some applications. Proc Natl Acad Sci USA 76, 4350-4354.

VINCENT, B., BEAUDET, A., DAUCH, P., VINCENT, J.P., and CHECLER, F. (1996). Distinct properties of neuronal and astrocytic endopeptidase 3.4.24.16: A study on differentiation, subcellular distribution, and secretion processes. J. Neurosci. 16, 5049-5059.

WU, T.J., PIEROTTI, A.R., JAKUBOWSKI, M., SHEWARD, W.J., GLUCKSMAN, M.J., SMITH, A.I., KING, J.C., FINK, G., and ROBERTS, J.L. (1997). Endopeptidase EC 3.4.24.15 in the rat median eminence and hypophysial portal blood, and its modulation of the luteinizing hormone surge. J. Neuroendocrin ol. 9, 813-822.

Address reprint requests to: Dr. James L. Roberts

Fishberg Research Center for Neurobiology, Box 1065 Mount Sinai Medical Center 1 Gustave Levy Place New York, NY 10029

E-mail: roberts@msvax.mssm.edu

Received for publication April 27, 1999; accepted in revised form June 25, 1999. 